\title{
Renovation in Curriculum Design and Textbook Development: An Effective Solution to Improving the Quality of English Teaching in Vietnamese Schools in the Context of Integration and Globalization
}

\author{
Hoang Van Van ${ }^{*}$ \\ Center of Linguistics and International Studies, \\ VNU University for Languages and International Studies, Pham Van Dong, \\ Cau Giay, Hanoi, Vietnam
}

Received 02 August 2016

Revised 26 September 2016; Accepted 22 December 2016

\begin{abstract}
There are many solutions to improving the quality of teaching and learning foreign languages in general and teaching and learning English in Vietnamese schools in particular. One of the most important solutions is probably the renovation in curriculum design and textbook development. This is the focus of this paper. The paper is organized around five main sections. Following Section 1 - Introduction, Section 2 provides an overview of the National Foreign Languages 2020 Project, focusing on the points related to the design of school English curriculum and the development of school English textbooks. Section 3 is concerned with the design of three pilot English curricula for Vietnamese schools and highlights their innovative points. Section 4 discusses in some detail the design and development of the ten-year English textbook series for Vietnamese schools under the National Foreign Languages 2020 Project and highlights its innovative points. Section 5 presents the achievements related to the development of the ten-year English textbook series. Finally, Section 6 summarizes the main points discussed in the paper and makes some recommendations for further improving the quality and the effect of use of the tenyear English textbook series before putting it into use on a large scale.
\end{abstract}

Keywords: The 2020 Project, the three pilot English curricula, the ten-year English textbook series, the six-level foreign language proficiency framework for Vietnam.

\section{Introduction}

In the world of today, international exchanges have been increasingly developing. Along with the ever increasing development of international exchanges, communication between nations, organizations, and people through language is also developing. The most

\footnotetext{
Tel.: 84-946296999

Email: vanhv@vnu.edu.vn
}

effective and indispensible means of communication to maintain and develop international exchanges is language. For this reason, the aim of teaching and learning a foreign language today is no longer limited to the teacher's providing the student with an understanding of the nature of the foreign language being learnt; neither is it limited to the teacher's asking the student to do lexical and grammatical exercises, or to develop one or two language skills such as reading or writing. 
Rather, the aim of teaching and learning a foreign language today is for communication in which the language elements such as pronunciation, vocabulary, and grammar (linguistic competence) are the means and the skills of listening, speaking, reading and writing (communicative competence) and the learner's cultural competence are the targets (the ends) which the teaching and learning process should target at so that when communicating with foreigners we can understand them and they can understand us. ${ }^{1}$ The two clauses "we can understand them" and "they can understand us" in a foreign language sound seemingly simple, but it has consumed a lot of effort and resources (human, material and financial) of many countries including Vietnam, forcing them to find effective solutions to improving their learners' standards of performance in foreign languages.

Overall, there are many solutions to improving the quality of any subject in schools, but they can be grouped into three levels: macro-level, meso-level and micro-level. At the macro-level, a solution that has the most powerful and spreading impact concerns the decision to renovate the subject (foreign languages in this case) by the government. Accompanying this solution is the promulgation of policies and the launching of propaganda activities to make people know and understand the decision and prepare for implementation. At the meso-level, the most important solution which many education systems in the world often choose as the starting point of the renovation process is to design a new curriculum and develop (a) new set(s) of textbooks for the subject. And at the microlevel, after the new curriculum is designed and the new set(s) of textbooks is/are developed, a number of activities (solutions) to improving the quality of teaching and learning the subject are proposed and implemented such as training and even retraining the subject teachers to meet the new performance standards, upgrading the infrastructure of the classroom, modernizing equipment and teaching aids, training teachers in the new methods and techniques to meet the requirements of the new curriculum and textbooks, promulgating a number of policies to encourage teachers and students to teach and learn the subject effectively, etc.

It is not possible to present all the solutions at all levels in a paper of this limited length. For this reason, of the solutions mentioned above, this paper chooses to look at only one solution at the meso-level with the specific title as: "Renovation in Curriculum Design and Textbook Development: An Effective Solution to Improving the Quality of the English Language Education in Vietnamese Schools". As the title indicates, this paper will focus on presenting and analyzing two renovation aspects: renovation in English curriculum design and renovation in English textbook development in Vietnamese schools under the National Foreign Languages 2020 Project. The paper is organized around five main sections. Following Section 1 - Introduction, Section 2 provides an overview of the National Foreign Languages 2020 Project, focusing on the points related to the design of school English curriculum and the development of school English textbooks. Section 3 is concerned with the design of three pilot English curricula for Vietnamese schools and highlights some of their innovative points. Section 4 discusses in some detail the design and development of the ten-year English textbook series for Vietnamese schools under the National Foreign Languages 2020 Project and highlights some of its innovative points. Section 5 presents the achievements related to the development of the ten-year English textbook series. And Section 6 summarizes the main points discussed in the paper and makes some recommendations for further improving the quality and the effect of use of the ten-year English textbook series before putting it into use on a large scale.

\footnotetext{
${ }^{1}$ Emphasis is mine.
} 


\section{The national foreign languages 2020 project}

Foreign language teaching and learning has always received deep concern from the Vietnamese Government. Looking back at the history of foreign language teaching and learning in Vietnam, one can see that since the 1960 s of the 20th century, the teaching of foreign languages has always taken up a rightful place in the language policy of Vietnam as a compulsory subject first at upper secondary level, and then from lower secondary level to post-graduate level. One can also affirm without hesitation that thanks to the constant concern of the Government, Vietnam has gradually achieved remarkable progress in the field of foreign language education in general and English language education in particular (cf. EF EPI [1]). This remarkable progress can be seen in different periods of Vietnamese foreign language teaching and learning: from the period in which English was taught without an explicit curriculum and textbooks in the 1970s to the period in which English was taught for 3 years (from grade 10 to grade 12) in the North and 7 years (from grade 6 to grade 12) in the South with two curricula implicitly designed for the two respective sets of English textbooks in the late 1970 s and early 1980 s, to the period in which English was taught for 7 years (from grade 6 to grade 12) throughout the country in which the curriculum was explicitly and systematically designed with one set of textbooks for lower secondary schools and two sets of textbooks (the standard set and the advanced one) for upper secondary schools. (For details, see Bộ Giáo dục và Đào tạo [MOET], [2]; Viện Khoa học Giáo dục Việt Nam [VNIES], [3, 4]).

Along with the advances in curriculum design and textbook development, the qualifications and communication skills of foreign language teachers in general and English teachers in particular in Vietnam have achieved encouraging progress. Some school teachers could conduct an entire lesson in English; many school students, especially those gifted ones could communicate in English with ease; and many of them have achieved very high scores in the two international tests: the TOEFL and the IELTS. However, in a world in which internationalization and integration are becoming an inevitable trend, the need for highskilled and highly qualified people who can communicate confidently in foreign languages, especially in English has become an urgent requirement for Vietnam. This urgent requirement has made it difficult for Vietnam to maintain its current standards of teaching, learning and use of foreign languages. Increasingly, decision-making bodies (the Government and MOET) were becoming aware that without a radical change in language policy, curriculum design, textbook development, teaching methodology and testing and assessment, Vietnam's standards of performance in foreign languages in general and in English in particular would be left behind. Being aware of the importance of improving the quality of teaching and learning foreign languages in the context of globalization, on September 30, 2008, the Prime Minister of the Government of the Socialist Republic of Vietnam signed Decision No. 1400/QĐ-TTg to promulgate the national project entitled "Teaching and Learning Foreign Languages in the National Education System, Period 2008-2020" [5] (hereinafter referred to as the 2020 Project).

The goal of the 2020 Project is to renovate thoroughly the tasks of teaching and learning foreign languages in the national education system, to implement a new foreign language programme at all educational levels and training degrees, so that by 2015 there will be an obvious progress in qualification and use of foreign languages of the Vietnamese human resources, especially in some prioritized sectors; and by 2020 most Vietnamese young people graduating from secondary vocational schools, colleges and universities will be able to use a foreign language confidently in their daily communication, their study and work in an integrated, multi- 
cultural and multi-lingual environment, making foreign languages a competitive advantage of the Vietnamese people ${ }^{2}$ to serve the cause of industrialization and modernization of the country".

The 2020 Project is composed of three phases. The first phase extends from 2008 to 2010; the second phase, from 2011 to 2015; and the third phase, from 2016 to 2020 . In the first phase, top priority is given to the design and perfection of the 10-year foreign language curricula for Vietnamese schools, focusing on the design of English curriculum; writing foreign language textbooks; preparing necessary conditions for trying out the 10-year foreign language programme. In the second phase, emphasis is laid on introducing the 10year foreign language programme into the whole general education system. And in the third phase, focus is on perfecting the 10-year foreign language programme throughout the general education system and on developing intensive foreign language programmes for secondary vocational schools, colleges and universities. The 2020 Project even encourages Vietnamese educational institutions to actively develop and carry out bilingual programmes.

In terms of standard, the 2020 Project explicitly adopts the 6 language proficiency level framework as developed in Council of Europe's Common European Framework of Reference for Languages: Learning, Teaching, Assessment (CEFR) [6] as the standards for curriculum design, textbook development, teaching methodology development and assessment (for more details, see Hoang Van $\operatorname{Van}[7,8])$.

Although there may be differences in opinion about the goal of the 2020 Project, the consensus is that it was promulgated in the right time. It is a decisive solution to improving the foreign language proficiency of the Vietnamese people. Since its promulgation, the 2020 Project has acted as the reference point for many activities implemented at the meso-level, and in

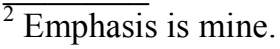

particular, it has been a solid legal corridor for foreign language curriculum design and foreign language textbook development in general and the design of the three pilot English curricula and the development of the ten-year English textbook series in particular which will be presented in some detail in the sections that follow.

\section{The design of the three pilot English curricula and their innovative points}

New challenge requires new objectives, and new objectives require a new curriculum (cf. Hawkin, [9, 5]). In implementing the Prime Minister's Decision 1400/QĐ-TTg, MOET assigned the VNIES to design three pilot English curricula for three levels of Vietnamese general education. The result was that three pilot English curricula for Vietnamese schools came into being: (i) Chuoong trình tiếng Anh thi điểm tiểu học (Pilot English Curriculum for Vietnamese Primary Schools) promulgated in accordance with Decision No. 3321/QĐBGDĐT, December 8, 2010 [10]; (ii) Chuong trình giáo duc phổ thông môn tiếng Anh thi điểm cấp trung hoc co sơ (Pilot English Curriculum for Vietnamese Lower Secondary Schools) promulgated in accordance with Decision No. 1/QĐ-BGDĐT, January 3, 2012 [11]; and (iii) Chương trình giáo duc phổ thông môn tiếng Anh thi điểm cấp trung họ phổ thông (Pilot English Curriculum for Vietnamese Upper Secondary Schools) promulgated in accordance with Decision No. 5209/QDBGDĐT, November 23, 2012 [12].

The three pilot English curricula for Vietnamese schools were designed with the close collaboration between curriculum designers of the VNIES and those from Vietnamese foreign language universities; in particular, they were designed with the participation of two famous British applied linguists from the British Council: Professor Rhona Stainthrop (for Pilot English Curriculum for Vietnamese Primary Schools) and Professor 
David Hay (for Pilot English Curriculum for Vietnamese Lower Secondary Schools and Pilot English Curriculum for Vietnamese Upper Secondary Schools). The design of the three pilot English curricula for Vietnamese schools drew on the insights of Council of Europe's CEFR [6] and Van Ek \& Alexanders' Threshold Level English [13]. In particular, it was based on the principles of communicative language teaching (cf. Breen \& Candlin, [14]; Munby, [15]; Richards, [16]; Richards \& Rodgers, [17]; Savignon, [18, 19]; Littlewood, [20]; see also Hoang Van Van, [21]) in combination with a consideration of the social and cultural realities (cf. Taba, [22]) of Vietnam, using selectively and creatively the insights of several curricula of English as a second/foreign language of countries in the region and in the world such as the USA, the UK, Singapore, Malaysia, Indonesia, China, Thailand, South Korea, and Japan. In terms of the structure, they are multi-component curricula, taking the development of communicative competence through four macro-skills (listening, speaking, reading and writing) as the focus, and seeing theme/topic, language elements (pronunciation, vocabulary, grammar) and intercultural aspects as the components that contribute to the comprehensive development of students' communicative competence in English.

Three innovative points can be seen in the three pilot English curricula for Vietnamese schools. First, unlike MOET's Chưong trình Giáo duc Phồ thông Môn tiếng Anh or Chương trình tiếng Anh 7 năm (English Curriculum for Vietnamese Schools or the Seven-year English Curriculum) [2], ${ }^{3}$ the three pilot English curricula for Vietnamese schools, as mentioned above, was designed with the participation of British curriculum designers. Secondly, the three pilot English curricula define clearly and

\footnotetext{
$\overline{3}$ English Curriculum for Vietnamese Schools (for lower and upper secondary schools) was designed in the late 1990s and was promulgated under Decision No. 16/2006/QĐ-BGDDT on 5 May, 2006 by the Minister of Education and Training.
}

consistently the levels of communicative competence school pupils are required to achieve at each grade and each level of education, reflecting a continuity of knowledge and skills from primary, to lower secondary, and to upper secondary level. And thirdly, the three pilot English curricula calibrated output standards equivalent ${ }^{4}$ to $\mathrm{CEFR}^{5}$ levels of communicative competence, using them as important bases for curriculum design, textbook development and the development of competence framework for each grade and each level of education. This is a professional approach to curriculum design, defining clearly the role of each component in the sequence: design (of curriculum) $\rightarrow$ application (textbook writing) $\rightarrow$ implementation (teaching, learning and testing \& assessment) (for more details, please see Hoang Van Van, 2015a). Whereby:

- At primary level: students are required to achieve CEFR Level A1 or VNFLPF (Sixlevel Foreign Language Proficiency Framework for Vietnam, 2014) [23] Level 1.

- At lower secondary level: students are required to achieve CEFR Level A2 or VNFLPF Level 2.

- At upper secondary level: Students are required to achieve CEFR Level B1 or VNFLPF Level 3.

To further clarify the points, based on the CEFR framework, the three pilot English curricula for Vietnamese schools explicate the communicative competence of each level as follows:

\footnotetext{
$\overline{4}$ Emphasis is mine. The implication here is that the outcomes as required in the three pilot English curricula for Vietnamese schools under the 2020 Project are equivalent to those outcomes of world advanced educational systems. Details of the equivalences are determined by Vietnam in accordance with the specific circumstance of Vietnam.

5 The CEFR (Common European Framework of Reference) framework was formulated in the 1970s. This framework has been adopted in European Community countries and has been widely used in many countries around the world. In recent years, this framework has been adapted in many Asian countries, including China, Japan, and South Korea to suit their educational contexts.
} 


\section{- Primary level}

Can understand and use familiar everyday expressions and very basic phrases aimed at the satisfaction of needs of a concrete type. Can introduce himself/herself and others and can ask and answer questions about personal details such as where he/she lives, people he/she knows and things he/she has. Can interact in a simple way provided the other person talks slowly and clearly and is prepared to help.

\section{- Lower secondary level}

Can understand sentences and frequently used expressions related to areas of most immediate relevance (e.g. very basic personal and family information, shopping, local geography, employment). Can communicate in simple and routine tasks requiring simple and direct exchange of information on familiar and routine matters. Can describe in simple terms aspects of his or her background, immediate environment and matters in areas of immediate need.

\section{- Upper secondary level}

Can understand the main points of clear standard input on familiar matters regularly encountered in work, school, leisure, etc. Can deal with most situations likely to arise whilst travelling in an area where the language is spoken. Can produce simple, connected text on topics which are familiar or of personal interest. Can describe experiences and events, dreams and hopes and ambitions and briefly give reasons and explanations for opinions and plans.

(Council of Europe, [6, 24])

\section{The development of the ten-year English textbook series and its innovative points}

In the renovation of teaching and learning, the writing of textbooks is a component of special importance. This is because textbooks are "agents of change" (Hutchinson \& Hutchinson, [24, 317]); they have direct impact on the teacher's teaching methodology and the student's learning styles; and, if properly used, they can not only contribute directly to the effectiveness of the teaching and learning process, but also "provide an excellent vehicle for effective long-lasting change" (Hutchinson $\&$ Hutchinson, [24, 317]). Being aware of the importance of writing new English textbooks for the new national 2020 Project, MOET assigned VNIES with the task of organizing the development of the ten-year English textbooks series for Vietnamese schools. At the same time MOET signed decisions to appoint a chief series author, chief grade authors, and authors for three levels of education: primary, lower secondary, and upper secondary.

Work on the design and development of the ten-year English textbook series began in mid of the second half of 2010. By the end of 2012 the primary English authors completed writing English 3, English 4 and English 5, and these were sent to 92 selected primary schools throughout Vietnam to try-out. However, in face of the urgent need to upgrade the ten-year English textbook series to regional and international standards, the Vietnam Education Publishing House (VEPH) found it a must to collaborate with international publishing partners. The result was that two collaborative agreements between VEPH and two world leading publishers were signed: one with MacMillan Education for developing primary English textbooks and the other with Pearson Education for developing lower secondary and upper secondary English textbooks. This is an important innovative point in foreign language textbook development in Vietnam: for the first time a Vietnamese publisher took the initiative lead to find foreign partners for collaboration on the basis of equality, mutual benefit in all aspects such as management, expertise and financial investment $^{6}$. Based on this collaborative

\footnotetext{
${ }^{6}$ Previously there had been a number collaborations with foreign countries in producing foreign language textbooks. In those collaborations, however, Vietnam was always in an inferior and passive position. This is because foreign countries were our donors and their co-authors were native speakers. Because of these we were dependent on their textbook writing approach and on their specifications of textbook contents. This often resulted in unfair collaborations and a short life span of the textbooks.
} 
framework, the three teams of Vietnamese authors (primary, lower secondary, and upper secondary) and their corresponding teams of the collaborative publishers work together almost at the same time to the principles and contents as specified in MOET's three pilot English curricula for Vietnamese schools.

The second innovative point worth noting is that, unlike the development of the English textbook series under MOET's Chuong trinh giáo dục phổ thông môn tiếng Anh (English Curriculum for Vietnamese General Education) [2], in the development of the ten-year English textbook series under the 2020 Project, MOET appointed a chief series author. The mission of the chief series author was to study carefully the three pilot English curricula; proposed principles for textbook development; and, in collaboration with the chief grade author and the authors of each grade and the authors of the two collaborative publishers, design the structure of the textbook for each grade, the structure of each learning unit, and the structure of each lesson; determine the contents related to language skills, language knowledge, and intercultural knowledge, the degrees of difficulty of the knowledge and skills at each level and each grade, and the level of skills and knowledge required to be achieved at each grade and at each level; and coordinate the writing activities of the textbooks to create the consistency and continuity of language knowledge, language skills, and cultural knowledge between grades and levels of the whole textbook series. The appointment of a chief series author is MOET's right decision as it helps create the continuity between grades and levels in the whole general education system, avoiding the "fracture" in approach, in levels of language knowledge and levels of language skills which often happened in the previous seven-year English textbook development where each level of the general education (lower secondary and upper secondary) had a separate chief series author.

The third innovative point is that the development of the ten-year English textbook series can be seen as a "cross-cultural collaboration" (Hoang Van Van, [21]) between Vietnamese authors and those of the two collaborative publishers. Over three years of working together, this partnership has proved to be very effective. It has succeeded in combining local expertise and experience in textbook writing of the Vietnamese authors with international expertise and experience in textbook development of native English authors. In the form of "Occidental-Oriental collaboration", it has succeeded in incorporating both the values of Vietnam and those of the world in the textbooks. It is challenging to the Vietnamese authors but it helps them improve their professional skills and broaden their horizons in the development of English textbooks in the context of integration. It is challenging to the authors of the two collaborative publishers but it helps them gain more experience and understand that English textbooks written by "outsiders" in order to serve specific learning objectives of the educational system of a particular country as they often do and think is entirely inappropriate, especially when we live in an interactive and interdependent world where one country does not depend on the other in a certain academic field.

What the Vietnamese authors and those of the two collaborative publishers have been collaborating together for over the last three years has proven that despite differences in culture, personality, and even in approach to textbook development, but with the strong desire to have a high quality series of English textbooks to serve more effectively the teaching and learning of English in Vietnamese schools, the authors have produced a new English textbook series for Vietnamese schools with the following innovative points.

1. The ten-year English textbook series adheres to the principles and the contents as required and specified in MOET's three pilot English curricula for Vietnamese schools.

2. The ten-year English textbook series is developed based on a multi-component approach, taking theme/topic as the starting 
point, the development of four macro-skills (listening, speaking, reading, writing) as the focus, and other components such as linguistic elements (pronunciation, vocabulary, and grammar) and intercultural aspects as the means to be taught so that together these components will contribute to the development of the school student's comprehensive communicative competence.
3. The ten-year English textbook series lays special emphasis on two oral skills (listening and speaking) at primary level; these skills are decreased gradually at lower secondary level so that at upper secondary level equal attention is paid to all the four macro-skills of listening, speaking, reading and writing. Details of the percentage for each language skill at each level of the textbook series are shown in Table 1.

Table 1. Percentage of listening, speaking, reading and writing at three levels of the ten-year English textbook series

\begin{tabular}{lcccc}
\hline & Listening & Speaking & Reading & Writing \\
\hline Primary & $35 \%$ & $35 \%$ & $15 \%$ & $15 \%$ \\
Lower secondary & $30 \%$ & $30 \%$ & $20 \%$ & $20 \%$ \\
Upper secondary & $25 \%$ & $25 \%$ & $25 \%$ & $25 \%$ \\
\hline
\end{tabular}

4. The ten-year English textbook series is organized around the topics familiar to the Vietnamese students and are suited to their age.

5. The development of ten-year English textbook series is based on the time frame as allocated in MOET's three pilot English curricula for Vietnamese schools. Thereby, the total time frame allocated for three levels of education is 1155 periods, of which 420 periods are allocated for primary level $/ 3$ years $=140$ periods/year; 420 periods for lower secondary level $/ 4$ years $=105$ periods $/$ year; and 315 periods for upper secondary level $/ 3$ years $=105$ periods/year. Based on the time frame allocated for each year of study, the English textbooks of each level are structured into the number of learning units, the number of periods of each learning unit, the number of periods for reviews and end-of-term tests, and the reserved time. Details of these are provided in Table 2.

Table 2. Time allocated for teaching, reviews, tests, reserves

\begin{tabular}{lccc}
\hline & $\begin{array}{c}\text { Time allocated for each } \\
\text { level of education and } \\
\text { each year of study }\end{array}$ & $\begin{array}{c}\text { Time allocated for } \\
\text { teaching }\end{array}$ & $\begin{array}{c}\text { Time allocated for reviews, } \\
\text { end-of term tests and reserves }\end{array}$ \\
\hline Primary & $420 / 140$ & $360 / 120$ & $60 / 20$ \\
Lower Secondary & $420 / 105$ & $336 / 84$ & $84 / 21$ \\
Upper Secondary & $315 / 105$ & $264 / 88$ & $51 / 17$ \\
Total & 1155 & 960 & 195 \\
\hline
\end{tabular}

6. The number of learning units and the number of review units of the textbook series are explicitly designed: 20 learning units and 4 review units for primary English, 12 learning units and 4 review units for lower secondary English; and 10 learning units and 4 review units for upper secondary English.

7. The structure of a learning unit in relation to the allocated teaching time is clearly explicated. Thereby, a learning unit of primary
English textbooks includes 3 lessons, each of which consists of two 35-minute periods; a learning unit of lower secondary English textbooks includes 7 lessons, each of which is a 45-minute period; and a learning unit of upper secondary English textbooks includes 8 lessons, each of which is a 45-minute period.

8. The number of learning units, the components and component headings of a learning unit, the number of period(s) for each 
heading are clearly designed to help teachers use the textbooks easily and effectively. Accordingly, a learning unit of primary English textbooks consists of 3 headings: Lesson 1, Lesson 2, and Lesson 3; a learning unit of lower secondary English textbooks includes 7 headings: Getting Started, A Closer Look 1, A Closer Look 2, Communication \& Culture, Skills 1 (Reading \& Speaking), Skills 2 (Listening \& Writing), Looking Back \& Project; and a learning unit of upper secondary English textbooks includes 8 headings: Getting Started, Language (Vocabulary,
Pronunciation, and Grammar), (Skills) Reading, Speaking, Listening, Writing, Communication \& Culture, Looking Back \& Project. Details of the number of learning units, the number of components in a learning unit, component headings and the number of period(s) for each component are presented in Table 3 below.

9. Among the existing varieties of English, the 10-year English textbook series chooses British accent for recording; the CDs were recorded by the authors of the collaborative publishers with a variety of English voices.

Table 3. Number of learning units, components and component headings of a learning unit and the time allocated for each component heading

\begin{tabular}{|c|c|c|c|}
\hline & Primary & Lower Secondary & Upper Secondary \\
\hline $\begin{array}{l}\text { Number of units of } \\
\text { study }\end{array}$ & 20 & 12 & 10 \\
\hline $\begin{array}{lr}\text { Number } & \text { of } \\
\text { components } & \text { per } \\
\text { learning unit } & \end{array}$ & 3 & 7 & 8 \\
\hline Component heading & $\begin{array}{l}\text { - Lesson } 1 \\
\text { - Lesson } 2 \\
\text { - Lesson } 3\end{array}$ & $\begin{array}{l}\text { - Getting Started } \\
\text { - A Closer Look } 1 \\
\text { - A Closer Look } 2 \\
\text { - Communication \& } \\
\text { Culture } \\
\text { - Skills } 1 \text { (Reading \& } \\
\text { Speaking) } \\
\text { - Skills } 2 \text { (Listening \& } \\
\text { Writing) } \\
\text { - Looking Back \& } \\
\text { Project }\end{array}$ & $\begin{array}{l}\text { - Getting Started } \\
\text { - Language (Vocabulary, } \\
\text { Pronunciation, } \\
\text { - Grammar) } \\
\text { - Reading } \\
\text { - Speaking } \\
\text { - Listening } \\
\text { - Writing } \\
\text { - Communication \& } \\
\text { - Culture } \\
\text { - Looking Back \& Project }\end{array}$ \\
\hline $\begin{array}{l}\text { Time allocated for } \\
\text { each heading }\end{array}$ & 2 periods & 1 period & 1 period \\
\hline
\end{tabular}

10. Different from the 7-year English textbooks series which was developed at the beginning of the 21 century, in the 10-year English textbook series the Teacher's Books were written in English and were integrated with the Student's Books to help teachers further enhance their English proficiency and use the Student's Books more conveniently and effectively.

11. The ten-year English textbooks series has eye-catching lay-out and high quality images, and is printed in four colors.
12. The ten-year English textbooks are evaluated by MOET's National Evaluation Council consisting of experts on English education both in Vietnam and abroad, experienced and highly qualified school teachers of English to ensure that the textbooks meet the requirements of a modern English textbook series in terms of language knowledge, language skills, and intercultural knowledge. 


\section{The results}

The three teams of Vietnamese authors and their counterparts of Macmillan Education and Pearson Education have completed the development of the ten-year English textbook series on schedule. They have completed writing three sets of primary English textbooks (each of which consists of 2 Student's Books, a Teacher's Book, a Workbook, and 2 audio CDs), four sets of lower secondary English textbooks (each of which includes 2 Student's Books, a Teacher's Book, a Workbook, 2 audio CDs), and three sets of upper secondary English textbooks (each of which includes 2 student's Books, a Teacher's Book, a Workbook, and 2 audio CDs).

\section{Conclusion and recommendations}

Thanks to the policy of the Vietnamese Government via the regular guidance of MOET, the completion of the design of the three pilot English curricula and of the development of the ten-year English textbook series for Vietnamese schools under the National Foreign Languages 2020 Project is a breakthrough solution to improving the quality of teaching and learning English in Vietnamese schools. Despite the fact that the three sets of English textbooks (primary, lower secondary, and upper secondary) were simultaneously developed, the Vietnamese authors in close collaboration with their MacMillan Education and Pearson Education colleagues have produced a coherent, systematic and high-quality series of English textbooks for Vietnamese schools. The English textbooks which are being tried out in selected schools are evaluated by the teachers as having good quality, clear structure, beautiful lay-out, friendly to teachers and students, and of regional and international standard, while their prices are cheap, suited to the purse of the Vietnamese parents, especially to those who are in remote and disadvantaged areas of Vietnam (for more details, please see Hoang Van Van,
[25]). Along with other solutions at meso-level such as renovations in teacher training and teacher retraining, in teaching methodology, and in testing and assessment, the ten-year English textbook series - an "agent of change" (Hutchinson \& Hutchinson, [24, 307]) - will certainly contribute its part to improving the quality of teaching and learning English in Vietnamese schools, and further, to meeting the goal of the 2020 Project.

However, despite being regarded as one of the three essential components of the teaching and learning circle (Hutchinson \& Hutchinson, [24, 310]; Allwright, [26]), textbooks are just a static one. A good textbook with poor teaching and learning will lead to poor learning outcomes. Similarly, a good textbook with inappropriate views of use will also lead to disappointing learning outcomes. For the new ten-year English textbook series to be improved in quality and used more effectively, the following recommendations are made to MOET:

1. Ask the teachers and students of the piloted schools to provide feedback to help the authors of the textbooks adjust the contents and degrees of difficulty of the textbooks before putting them into use on a large scale.

2. Provide textbook authors with chances to observe classes and to talk with the teachers and students who are piloting the textbooks so that they can improve the textbooks to make them more suited to the English teaching and learning contexts of Vietnam.

3. Direct to make the introduction and employment of the ten-year English textbook series part of the annual teacher retraining programme.

4. Direct more intensively the building of a standard foreign language classroom (including standard teachers, standard students, standard teaching and learning facilities, and standard number of students/class) to make the teaching and learning of English in Vietnamese schools more effective.

5. Direct to make plans for training and retraining school teachers so that they will be 
able to exploit the textbook series effectively, contributing to meeting MOET's learning outcome requirement - after leaving upper secondary school, students must achieve VNFLPF Level 3 or CEFR B1.

\section{References}

[1] IF EPI. (The Education First English Proficiency Index), 2012, 2013, 2014, 2015. Retrieved from http://www.ef.com.vn/epi/

[2] Bộ Giáo dục và Đào tạo [MOET], Chương trình giáo dục phổ thông môn tiếng Anh (English Curriculum for Vietnamese Schools). (Ban hành theo Quyết định Số: 16/2006/QĐ-BGDĐT ngày 05 tháng 5 năm 2006 của Bộ trưởng Bộ Giáo dục và Đào tạo), 2006.

[3] Viện Khoa học Giáo dục Việt Nam [VNIES], Đề án dạy và học ngoại ngữ trong hệ thống giáo dục quốc dân giai đoạn 2008-2020 (Teaching and Learning Foreign Languages in the National Education System, Period 2008-2020). Tài liệu không xuất bản, Hà Nội - 2008.

[4] Viện Khoa học Giáo dục Việt Nam [VNIES], Tổng kết nghiên cứu về chương trình giáo dục phổ thông Việt Nam từ năm 1945 đến nay (An Evaluative Report on the Development of Vietnamese General Education Curricula from 1945 to the Present), Tài liệu không xuất bản, Hà Nội - 12/2012.

[5] Thủ tướng Chính phủ [Prime Minister of SRV], Đề án "Dạy và học ngoại ngữ trong hệ thống giáo dục quốc dân, giai đoạn 2008-2020" (Teaching and Learning Foreign Languages in the National Education System, Period 20082020). (Ban hành theo Quyết định Số: 1400/QĐTTg ngày 30 tháng 9 năm 2008 của Thủ tướng Chính phủ), 2008.

[6] Council of Europe, Common European Framework of Reference for Languages: Learning, Teaching, and Assessment (CEFR). Cambridge: Cambridge University Press, 2001.

[7] Hoàng Văn Vân, The Current Situation and Issues of the Teaching of English in Vietnam. Ritsumikan Studies in Language and Culture, Vol. 22 No.1. Pp. 7-18. 2010.

[8] Hoàng Văn Vân, The Role of Textbooks in the Implementation of the National Project "Teaching and Learning Foreign Languages in the National Education System, Period 20082020". Proceedings of the International Conference on Textbooks for the $21^{\text {th }}$ Century Held in Hanoi, 2011. Reprinted in Khoa học Ngoại ngữ, Số 30, Năm 2012. Trang 75-89.

[9] Hawkins, E., Modern Languages in the Curriculum. Cambridge: Cambridge University Press, 1981

[10] Bộ Giáo dục và Đào tạo [MOET], Chương trình tiếng Anh thí điểm tiểu học (Pilot English Curriculum for Vietnamese Primary Schools). (Ban hành theo Quyết định Số: 3321/QĐBGDĐT ngày 12 tháng 8 năm 2010 của Bộ trưởng Bộ Giáo dục và Đào tạo), 2010.

[11] Bộ Giáo dục và Đào tạo [MOET], Chương trình giáo dục phổ thông môn tiếng Anh thí điểm cấp trung học cơ sở (Pilot English Curriculum for Vietnamese Lower Secondary Schools). (Ban hành theo Quyết định Số: 01/QĐ-BGDĐT ngày 03 tháng 01 năm 2012 của Bộ trưởng Bộ Giáo dục và Đào tạo), 2012.

[12] Bộ Giáo dục và Đào tạo [MOET], Chương trình giáo dục phổ thông môn tiếng Anh thí điểm cấp trung học phổ thông (Pilot English Curriculum for Vietnamese Upper Secondary Schools). (Ban hành theo Quyết định Số: 5290/QĐ-BGDĐT ngày 23 tháng 11 năm 2012 của Bộ trưởng Bộ Giáo dục và Đào tạo), 2012.

[13] Van Ek, J. A. \& L. G. Alexander, Threshold Level English. Oxford: Pergamon. 1980.

[14] Breen, M. P. \& C. N. Candlin. The Essentials of a Communicative Curriculum in Language Teaching. (In) Applied Linguistics, Vol. 1, No. 2. 1980. Pp. 89-112.

[15] Munby, J., Communicative Syllabus Design. Cambridge: Cambridge University Press, 1997.

[16] Richards, J. C., Curriculum Development in Language Teaching. Cambridge: Cambridge University Press, 2001.

[17] Richards, J. C. \& T. S. Rodgers, Approaches and Methods in Language Teaching. Second Edition. Cambridge: Cambridge University Press, 2004.

[18] Savignon, S. J., Communicative Language Teaching: State of the Art. (In) TESOL QUARTERLY. Vol. 25, No. 2. Summer 1991. Pp. 261-276.

[19] Savignon, S. J., Interpreting Communicative Language Teaching: Context and Concerns in Teacher Education. New Haven \& London: Yale University Press, 2002.

[20] Littlewood, W., Communicative Language Teaching: An Introduction. Twenty Second 
Printing. Cambridge: Cambridge University Press, 2002.

[21] Hoàng Văn Vân (2015a). The Development of the Ten-year English Textbook Series for Vietnamese Schools under the National Foreign Language 2020 Project: A Cross-cultural Collaborative Experience. Paper Addressed at the Plenary Session of the International TESOL Symposium: English Language Innovation, Implementation, and Sustainability, Held in Danang, Vietnam on 28-29 July, 2015. Reprinted in VNU Journal of Science - Foreign Studies. Vol. 31. $\mathrm{N}_{0}$. 3. 2015. Pp. 1-17.

[22] Taba, H., Curriculum Development: Theory and Practice. New York: Harcourt, Brace \& World, Inc., 1962.

[23] Bộ Giáo dục và Đào tạo [MOET], Khung năng lực ngoại ngữ 6 bậc dùng cho Việt Nam (Sixlevel Foreign Language Proficiency Framework for Vietnam). (Ban hành kèm theo
Thông tư Số: 01/2014/TT-BGDĐT ngày 24 tháng 01 năm 2014 của Bộ trưởng Bộ Giáo dục và Đào tạo), 2014.

[24] Hutchinson, T. \& U. G. Hutchinson, Textbook as Agent of Change. (In) Power, Pedagogy and Practice. Hedge, T. \& N. Whitney (Eds.). Oxford: Oxford University Press, 1997. Pp. 307-323.

[25] Hoàng Văn Vân, Teacher's Evaluation of Primary English Textbooks for Vietnamese Schools under the National Foreign Language Project 2020: A Preliminary Internal Survey. Proceedings of the VietTESOL International Conference Held at Hanoi University of Education on November 27, 2015. Reprinted in VNU Journal of Science - Education Research. Vol. 31. $\mathrm{N}_{0}$. 4. 2015. Pp. 1-15.

[26] Allwright, R. L., What do We Want Teaching Materials for? (In) Currents of Change in English Language Teaching. Oxford: Oxford University Press. Pp. 131-147. 